MATEC Web of Conferences 9, 04002 (2013)

DOI: $10.1051 /$ matecconf/20130904002

(C) Owned by the authors, published by EDP Sciences, 2013

\title{
Fire safety of EPS insulated facades in residential multi-storey buildings
}

\author{
Esko Mikkola ${ }^{1}$, Tuula Hakkarainen ${ }^{2}$ and Anna Matala ${ }^{2}$ \\ ${ }^{1}$ KK-Fireconsult Ltd, Espoo, Finland \\ ${ }^{2}$ VTT Technical Research Centre of Finland, Espoo, Finland
}

\begin{abstract}
Effect of EPS ETICS system on fire safety has been studied by using fire safety engineering methods for residential multi-storey buildings up to eight floors. The probabilities of fire spread to apartments above the room-of-fire-origin were assessed by calculating heat exposures and consequences caused by the external flaming both for the EPS ETICS facade and for facade made of at least A2-s1, d0 materials. Concerning consequences for life safety, the fire death probability for EPS ETICS system was found to be within tolerable limits of F-N-curve which illustrates the probability of an event and consequences in terms of number of deaths. Special concern should be paid to fire safety during installation phase when EPS is unprotected without reinforced rendering.
\end{abstract}

\section{INTRODUCTION}

Energy efficiency and overall needs for sustainable buildings are increasing the use of efficient thermal insulation systems. In national regulations and guidelines limitations or protection requirements may be specified for the use of combustible insulation in facades. Alternatively, there may be performance based requirements for products or for the whole facade system defining fire performance levels for different applications.

This study aims to determine the effect of EPS ETICS (External Thermal Insulation Composite Systems) insulation for fire safety when used in external wall and to produce justification for required protective methods. The study covers residential multi-storey buildings up to eight floors. In addition, an assessment concerning the construction or renovation time is also done. The statistical data utilised cover Finland and Sweden.

The analysis focuses on fires starting inside buildings and uses data on room areas and fire loads of typical dwellings in multi-storey buildings. External ignitions do not cause more severe exposures on the facade than flashover room fires. Also the number of external ignitions is substantially lower compared to those ignited inside buildings.

Modelling of the spreading of a flash-over room fire takes into account the development of fire in the room-of-fire-origin, spreading through breaking window to the facade and external flaming. Using the Monte Carlo technique [1], the probabilities of fire spread to apartments above the room-of-fire-origin are assessed both for the EPS insulated facade and for at least A2-s1, d0 facade. More details are given in a recent technical report [2].

\section{USE OF EPS INSULATION IN EXTERNAL WALLS}

The following types of EPS insulation are included in this study: with and without flame retardant as white and grey (= graphite containing) qualities (densities between 15 and $22 \mathrm{~kg} / \mathrm{m}^{3}$ ). In renovation, the

This is an Open Access article distributed under the terms of the Creative Commons Attribution License 2.0, which permits unrestricted use, distribution, and reproduction in any medium, provided the original work is properly cited. 


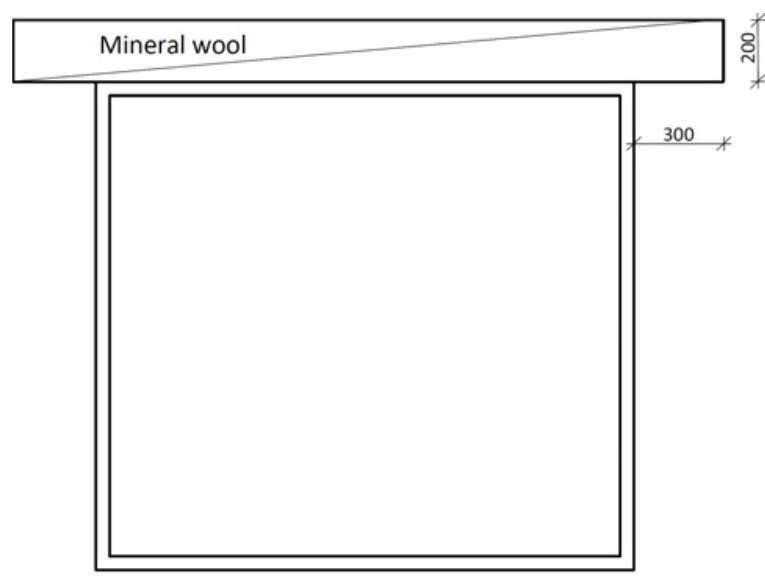

Fire stops (at least A2-s1, d0 class mineral wool): $200 \mathrm{~mm}$ above each window, or continuous $300 \mathrm{~mm}$ barrier at every second floor

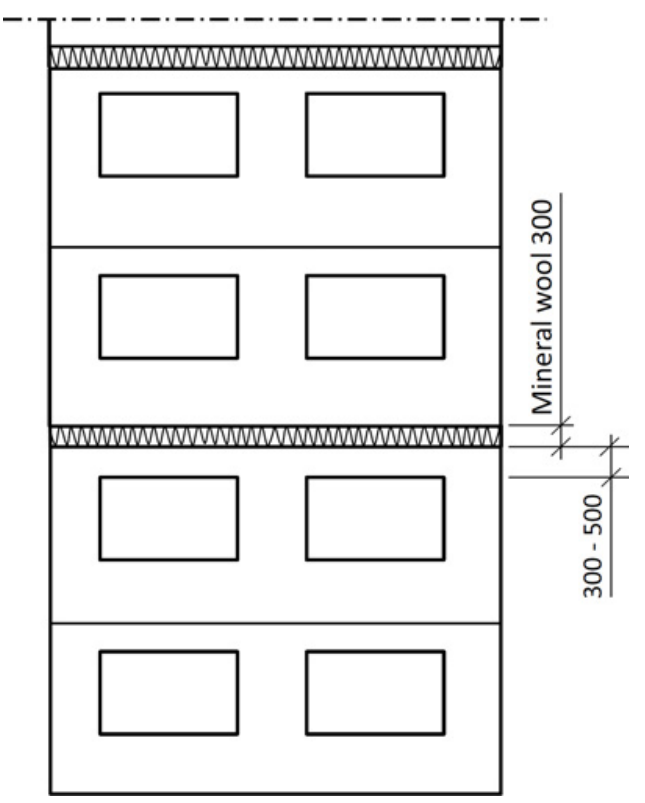

Figure 1. Examples of fire stop/barrier alternatives for buildings with more than two floors when EPS insulation is used in external walls [4].

additional new insulation may be $50 \mathrm{~mm}$ as a minimum thickness, and in new buildings the thickness can be up to $300 \mathrm{~mm}$. In the end use, EPS insulation is protected against direct fire exposure from all sides. In this study it is assumed that EPS insulation is protected from internal fires by structures with fire separating function of at least EI 30. When EPS insulation is protected from external side with approved reinforced rendering system (ETICS, which fulfil requirements of ETAG 004 [3] including fire performance of components and the system), fire stops described in Figure 1 are used to prevent fire spread in the insulation layer in buildings with more than two floors.

\section{STATISTICAL BACKGROUND FOR FACADE FIRES}

To establish the statistical basis for studying the effect of EPS insulation used in external wall on the fire safety of the building, a statistical survey was carried out on the data stored in the Statistics system of the Finnish rescue services (PRONTO) and in the Statistics database of the Swedish Civil Contingencies Agency (IDA). The survey concerned fires in residential multi-storey buildings and the role of the facade material in these fires. The years covered in the survey are 2004-2012 for PRONTO and 2004-2011 for IDA.

According to statistics, the fire is extinct without fire brigade intervention (and thus not capable of spreading out of the compartment of fire origin) in about $15-30 \%$ of the fires.

By the arrival of the fire brigade, the fire development situation is the following for spread of fire outside the fire compartment: from 1\% (Sweden) to 3-4\% (Finland) per ignited fire.

Information on fire spread due to window breaking (according to Finnish statistics) indicated that $0.7 \%$ of cases could lead to spreading through windows.

A limited amount of data is available about the involvement of EPS insulation in fires, and only a few incidents were found related to construction or renovation work. The ignition of EPS insulation seems to be relatively rare, indicating that an adequate protection is usually provided. 
$1^{\text {st }}$ International Seminar for Fire Safety of Facades, Paris (France), 2013

Table 1. Cone Calorimeter results for grey EPS compared with earlier results for white EPS at $50 \mathrm{~kW} / \mathrm{m}^{2}$ exposure level.

\begin{tabular}{|c|c|c|c|c|c|c|}
\hline \multicolumn{7}{|c|}{ EPS withoutflame retardant } \\
\hline & \multirow{2}{*}{\multicolumn{2}{|c|}{ Grey EPS }} & \multicolumn{4}{|c|}{ White EPS } \\
\hline & & & [6] & [7] & {$[8,9]^{1}$} & {$[8,9]^{2}$} \\
\hline Density $\rho\left(\mathrm{kg} / \mathrm{m}^{3}\right)$ & 18 & 18 & 20 & 15 & 16 & 16 \\
\hline Thickness d (mm) & 25 & 50 & 50 & 25 & 25 & 25 \\
\hline Time to ignition (s) & 41 & 35 & 37 & 18 & 26 & 68 \\
\hline $\mathrm{RHR}_{\max }\left(\mathrm{kW} / \mathrm{m}^{2}\right)$ & 411 & 343 & 410 & 407 & 507 & 477 \\
\hline $\mathrm{RHR}_{60 \mathrm{~s}}\left(\mathrm{~kW} / \mathrm{m}^{2}\right)$ & 218 & 306 & 345 & 158 & - & - \\
\hline THR $\left(\mathrm{MJ} / \mathrm{m}^{2}\right)$ & 13.3 & 26.5 & - & - & 16.9 & 17.3 \\
\hline Smoke; SEA $\left(\mathrm{m}^{2} / \mathrm{kg}\right)$ & - & - & 1120 & 1346 & 1174 & 977 \\
\hline
\end{tabular}

${ }^{1}$ No protection.

${ }^{2}$ Steel sheet $(0.6 \mathrm{~mm})$ protection.

Table 2. Cone Calorimeter results for grey and white EPS with flame retardant compared with earlier results for white EPS at $50 \mathrm{~kW} / \mathrm{m}^{2}$ exposure level.

\begin{tabular}{|c|c|c|c|c|c|c|c|c|c|}
\hline \multicolumn{10}{|c|}{ EPS withflame retardant } \\
\hline & \multirow{2}{*}{\multicolumn{2}{|c|}{ Grey EPS }} & \multicolumn{7}{|c|}{ White EPS } \\
\hline & & & & & [6] & [7] & \multicolumn{3}{|c|}{$[8,9]$} \\
\hline Density $\rho\left(\mathrm{kg} / \mathrm{m}^{3}\right)$ & 19 & 19 & 22 & 22 & 22 & 15 & 16 & 16 & 16 \\
\hline Thickness d (mm) & 25 & 50 & 25 & 50 & 50 & 25 & 25 & 25 & 20 \\
\hline Time to ignition (s) & 48 & 46 & 56 & 46 & 46 & 24 & 37 & 83 & 198 \\
\hline $\mathrm{RHR}_{\max }\left(\mathrm{kW} / \mathrm{m}^{2}\right)$ & 325 & 329 & 265 & 330 & 380 & 379 & 306 & 97 & 77 \\
\hline $\operatorname{RHR}_{60 \mathrm{~s}}\left(\mathrm{~kW} / \mathrm{m}^{2}\right)$ & 172 & 290 & 202 & 293 & 320 & 173 & - & - & - \\
\hline $\operatorname{THR}\left(\mathrm{MJ} / \mathrm{m}^{2}\right)$ & 13.9 & 27.6 & 16.5 & 32.7 & - & - & 14.9 & 18.6 & 20.2 \\
\hline Smoke; SEA $\left(\mathrm{m}^{2} / \mathrm{kg}\right)$ & - & - & - & - & 1220 & 1297 & 1394 & 1004 & 609 \\
\hline
\end{tabular}

${ }^{1}$ No protection.

${ }^{2}$ Steel sheet $(0.6 \mathrm{~mm})$ protection.

${ }^{3}$ Steel sheet $(0.6 \mathrm{~mm})+4.5 \mathrm{~mm}$ fibre-cement board protection.

\section{FIRE PERFORMANCE OF EPS UNDER DIFFERENT CONDITIONS}

Fire performance parameters for white and grey (containing carbon/graphite) EPS with and without flame retardants were measured using the Cone Calorimeter method [5]. In this study experiments were carried out at $50 \mathrm{~kW} / \mathrm{m}^{2}$ exposure and compared with literature values (see Table 1 and Table 2).

At the heat flux level of $50 \mathrm{~kW} / \mathrm{m}^{2}$ there are only small differences between the products with and without flame retardant. The efficiency of flame retardant comes more significant at lower heat fluxes: EPS with flame retardant did not ignite at $20 \mathrm{~kW} / \mathrm{m}^{2}$, but EPS without flame retardant ignited at $15 \mathrm{~kW} / \mathrm{m}^{2}$ [8]. The experimental results also show very clearly the protective effect of thin steel sheet $(0.6 \mathrm{~mm})$ and $4.5 \mathrm{~mm}$ thick fibre-cement board.

In the EPS ETICS system, the EPS insulation is protected with reinforced rendering $(5-8 \mathrm{~mm})$ which does not ignite or whose contribution to fire is limited. According to reference [8], ignition of steel sheet $(0.6 \mathrm{~mm})+4.5 \mathrm{~mm}$ fibre-cement board protected EPS takes about 2.5 minutes at heat flux level $60 \mathrm{~kW} / \mathrm{m}^{2}$, about 4 minutes at $40 \mathrm{~kW} / \mathrm{m}^{2}$ and more than 15 minutes at $30 \mathrm{~kW} / \mathrm{m}^{2}$. Similarly, RHR $_{\max }$ is $91 \mathrm{~kW} / \mathrm{m}^{2}$ at heat flux level $60 \mathrm{~kW} / \mathrm{m}^{2}, 65 \mathrm{~kW} / \mathrm{m}^{2}$ at heat flux level $40 \mathrm{~kW} / \mathrm{m}^{2}$ and almost zero at $30 \mathrm{~kW} / \mathrm{m}^{2}$ for this mechanically protected specimen. Thus, the average rate of heat release from steel sheet $(0.6 \mathrm{~mm})+4.5 \mathrm{~mm}$ fibre-cement board protected EPS can be assumed to be not more than 
MATEC Web of Conferences

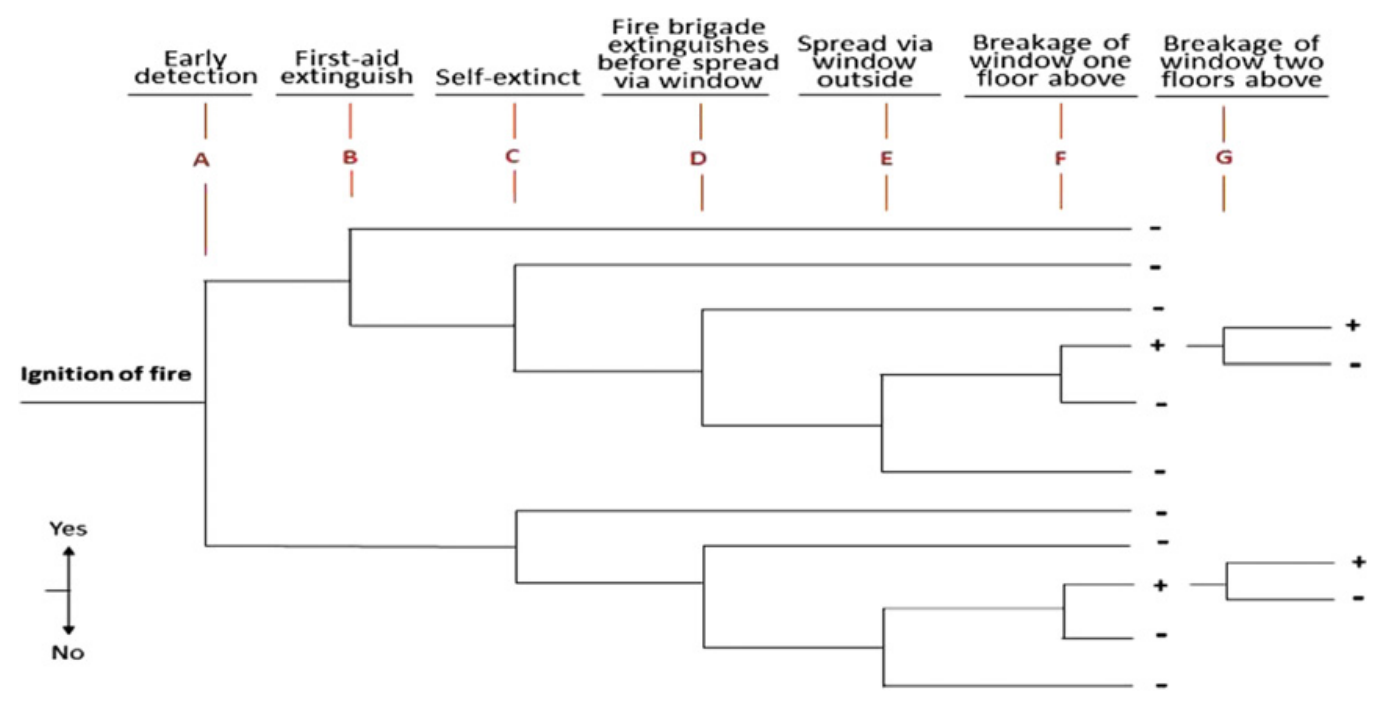

Figure 2. Event tree describing spread of fire from ignition to apartments above. Breakage of window is indicated by "+" and no breakage by "-".

$50 \mathrm{~kW} / \mathrm{m}^{2}$ for heat flux levels up to $60 \mathrm{~kW} / \mathrm{m}^{2}$. 5-8 mm thick reinforced rendering can be assumed to be as good protection for EPS as the thin steel sheet $+4.5 \mathrm{~mm}$ thick fibre-cement board because the heat transfer through fibre-cement board and rendering are quite similar. In the following analysis $50 \mathrm{~kW} / \mathrm{m}^{2}$ is used as an average value for rate of heat release from rendering protected EPS. In the sensitivity analysis a double value, $100 \mathrm{~kW} / \mathrm{m}^{2}$, is used to cover possible worst case situations.

There is also large scale experimental evidence on fire performance of EPS-rendering systems made in the following scale/conditions: specimen size above fire room 5-6 m and fire load 300-600 MJ $/ \mathrm{m}^{2}$ [10]. Maximum heat flux at the window above fire room, maximum temperature at the upper edge level of the specimen and limitation of burnt area to the lower edge of the window two floors up from the fire room are examples of acceptance criteria in these tests. In successful experiments EPS has contributed to the fire only on a limited area and no fire spread beyond the two floors above the fire room has occurred.

\section{EVENT TREE ANALYSIS}

Development and spreading of fire, breaking of windows above the fire room and interdependence of the different phases are illustrated in Figure 2 by using an event tree. Probabilistic branching values for this event tree are obtained partly from fire statistics and partly from simulations of room fire development and spreading.

\section{ANALYSIS OF ROOM FIRE SPREAD VIA FACADE TO COMPARTMENTS ABOVE}

The fire is assumed to start from an apartment and spread to the facade through a broken window. The grid cell size of the simulations was $0.2 \mathrm{~m}$ and the simulations were done using Fire Dynamics Simulator (FDS) program [11] version 6. The statistical study was made using Monte Carlo simulations (MC). 200 random cases (using Latin Hypercube sampling) were simulated using the parameters and distributions listed in Table 3.

It was assumed that the window breaks in the fire room when the window temperature at any point of the window area exceeds $500{ }^{\circ} \mathrm{C}$ during a time defined by a random variable (average of 3 minutes and $80 \%$ fractal at 5 minutes) [12]. These assumptions are based on windows having double glazing. 
$1^{\text {st }}$ International Seminar for Fire Safety of Facades, Paris (France), 2013

Table 3. Random variable distributions in Monte Carlo-simulations.

\begin{tabular}{|l|l|l|}
\hline Variable & Distribution & Parameters \\
\hline Room area $\left(\mathrm{m}^{2}\right)$ & Uniform & 7,30 \\
\hline Window wall length (proportional) & Uniform & $0.25,0.75$ \\
\hline Window height $(\mathrm{m})$ & Uniform & $1.2,1.4$ \\
\hline Window width $(\mathrm{m})$ & Uniform & 1,3 \\
\hline Fire load $\left(\mathrm{MJ} / \mathrm{m}^{2}\right)$ & Triangular & $200,600,1000$ \\
\hline Time delay to window break $(\mathrm{min})$ & Log-normal & $1.099,0.610$ \\
\hline Time to fire peak $(\mathrm{s})$ & Uniform & 300,2700 \\
\hline
\end{tabular}

Triple glazing may further delay fire spread through the window and this can be taken as a safety factor for this type of windows. The peak heat release rate is calculated so that the total fire load (determined by the random variable between 200 and $1000 \mathrm{MJ} / \mathrm{m}^{2}$ ) is consumed. This fire load range is based on experimental data on real fire loads in apartment buildings [13-16]. The fire exposure at the windows at upper floors is considered to be able to cause window breakage if the heat flux exceeded $35 \mathrm{~kW} / \mathrm{m}^{2}$ for at least 3 minutes [12].

\section{Fire exposure and fire spread on facade}

In a facade fire test method SP Fire 105, the rate of heat release has been measured to be about $2.5 \mathrm{MW}$ at maximum [17] when 601 of heptane is burnt as a fire load and the heat flux levels one floor above the fire room are over $30 \mathrm{~kW} / \mathrm{m}^{2}$ in this test. Experimental results for typical dwelling room flash-over fires show that at the window one floor above the fire room heat fluxes can be as a short-term up to $70-75 \mathrm{~kW} / \mathrm{m}^{2}[18-20]$ In the simulations the maximum heat fluxes were found to be about $80 \mathrm{~kW} / \mathrm{m}^{2}$ (except immediately after window breaking when the heat flux can be much higher for a short period, see Fig. 3). In the experiments no window was in place and thus the first peak seen in the simulation is missing.

\section{Simulation results of fire spread}

The comparison of probabilities for at least A2-s1, d0 and EPS insulated facades are done in Figure 4 as cumulative probabilities. The second floor window was broken in $31 \pm 5 \%$ with at least A2-s1, d0 facade and in $36 \pm 5 \%$ of the cases with EPS insulation. Until about 25 minutes from the start of the fire the window breaking time probabilities for both facade types are very close to each other (within one minute difference). In third floor the final probabilities were the same $(5 \pm 1 \%)$, but with EPS insulation the window breaking tends to occur slightly earlier. These are relative numbers per fires which have spread through the fire room window to the facade.

The analysis of effects by inner corners indicated that it is unlikely that the rendering protected EPS ignites under room fire exposure if the window edge is at least $1 \mathrm{~m}$ from the corner wall. Another result was that two floors above no window was broken when the fire room window width was maximum $1.5 \mathrm{~m}$.

\section{Conclusions on fire spread analysis}

The event tree approach is used to summarise the results received from statistics and simulations and finally to compare the overall probabilities for window breaking at floors above the fire room. Branching probabilities for the event tree based on literature values, statistics and simulations are given in the upper part of Table 4. 


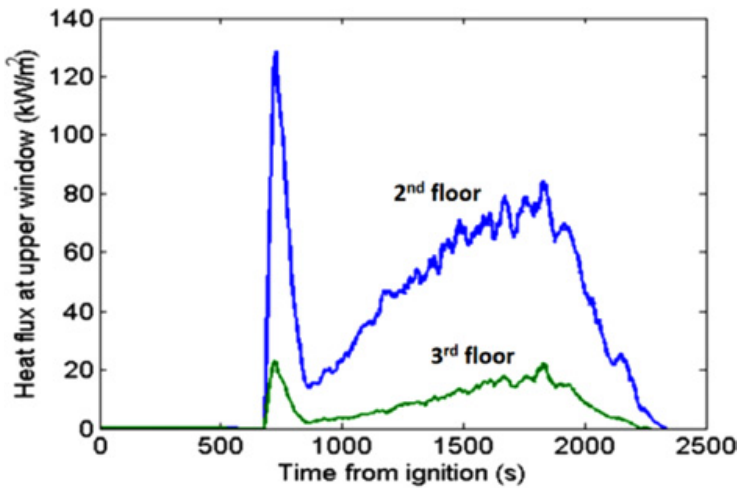

Figure 3. Example of maximum simulated heat fluxes at $2^{\text {nd }}$ and $3^{\text {rd }}$ floor window level.

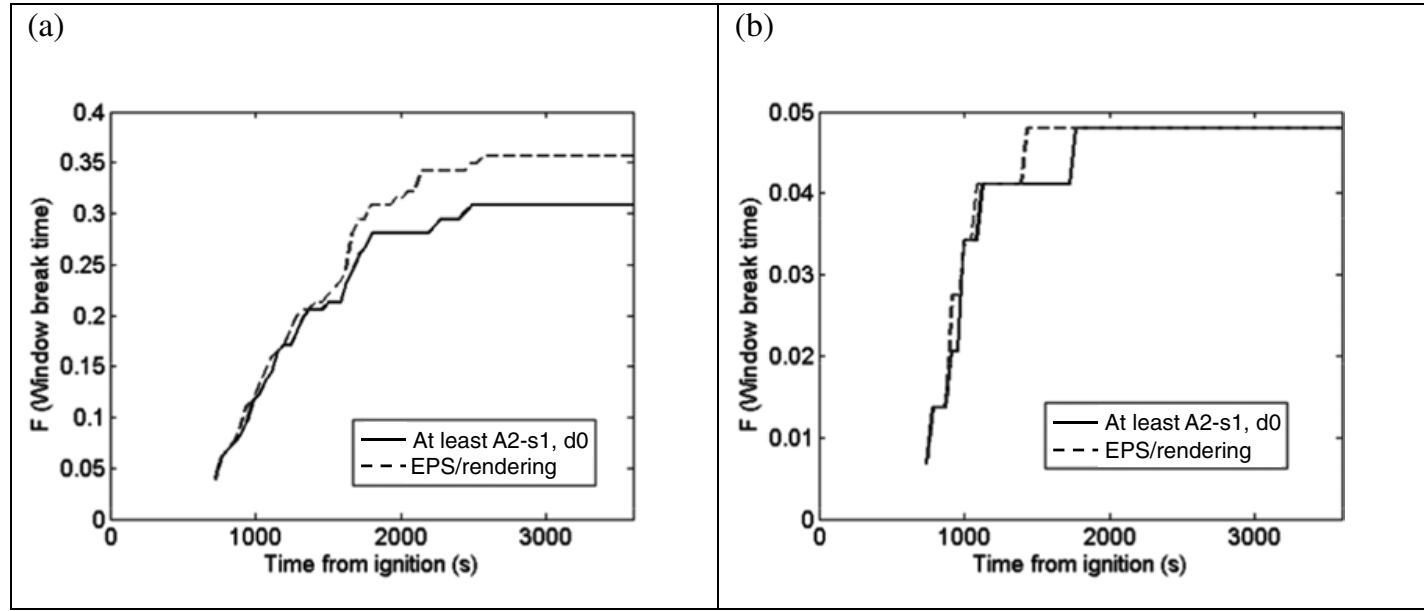

Figure 4. Window break results for at least A2-s1, d0 and EPS insulated facades. The probabilities are calculated from the cases where fire spread through window to the facade. a) Second floor. b) Third floor.

The accident statistics based limit value for probability of fire spreading to the apartments above are compared with event tree analysis estimates in the bottom part of Table 4 . Using the event tree of Figure 2 the sum for probabilities of breakage of window 1 and 2 floors above were calculated to be $1.9 \%$ for at least A2-s1, d0 facade and $2.3 \%$ for EPS ETICS facade per ignited fire. These estimates are on the upper limit of statistical data for which conservative values were used. Thus a safety factor is included in the results.

\section{PERFORMANCE CRITERIA FOR LIFE SAFETY}

Life safety risks caused by fires in residential buildings can be assessed by using ignition frequencies and estimated probabilities of spreading of fires. In Finnish residential multi-storey buildings ignition frequency per floor area according to accident statistics is not more than $7.5 \cdot 10^{-6} 1 / \mathrm{m}^{2} \mathrm{a}[21,22]$. Using $70 \mathrm{~m}^{2}$ as a mean floor area for apartments, the average probability of ignition of a fire in an apartment will be $5 \cdot 10^{-4}$ per year.

Earlier it was estimated that maximum $2 \%$ of multi-storey apartment building fires may spread to apartments above the initial fire compartment through windows when the surface and insulation of an 
$1^{\text {st }}$ International Seminar for Fire Safety of Facades, Paris (France), 2013

Table 4. Probabilities used in the event tree analysis and overall probabilities compared with statistical estimates.

\begin{tabular}{|l|c|c|c|}
\hline $\begin{array}{l}\text { Probabilities in the } \\
\text { branches of event } \\
\text { tree and } \\
\text { overall probabilities }\end{array}$ & $\begin{array}{c}\text { Statistical data } \\
\text { At least/nearly A2- } \\
\text { s1, d0 facade }\end{array}$ & $\begin{array}{c}\text { Data used and } \\
\text { results of } \\
\text { simulations } \\
\text { At least A2-s1, d0 }\end{array}$ & $\begin{array}{c}\text { Data used and } \\
\text { results of } \\
\text { simulations } \\
\text { EPS/rendering }\end{array}$ \\
\hline Early detection of fire & $0.15-0.25$ & $0.7^{[12]}$ & $0.7^{[12]}$ \\
\hline $\begin{array}{l}\text { First-aid extinguishing } \\
\text { successful }\end{array}$ & $0.1-0.15$ & 0.2 & 0.2 \\
\hline Self-extinction of fire & $0.8-0.95$ & 0.9 & 0.15 \\
\hline $\begin{array}{l}\text { Fire brigade extinguishes } \\
\text { before spread via window }\end{array}$ & & 0.73 & 0.9 \\
\hline Fire spreads via window & & 0.31 & 0.36 \\
\hline $\begin{array}{l}\text { Breakage of window 1 floor } \\
\text { above of fires spreading via } \\
\text { window }\end{array}$ & & & 0.16 \\
\hline $\begin{array}{l}\text { Breakage of window 2 floors } \\
\text { above of fires breaking } \\
\text { window 1 floor above }\end{array}$ & & & \\
\hline
\end{tabular}

window 1 floor above

\begin{tabular}{|c|c|c|c|}
\hline \multicolumn{4}{|l|}{ Overall probabilities } \\
\hline Breakage of window 1 floor above & & $1.66 \%$ & $1.95 \%$ \\
\hline Breakage of window 2 floors above & & $0.26 \%$ & $0.31 \%$ \\
\hline Breakage of window 1 or 2 floors above & $<0.7 \%-2 \%$ & $1.9 \%$ & $2.3 \%$ \\
\hline
\end{tabular}

external wall is made of at least A2-s1, d0 or nearly the same fire performance (= at least B-s1, d0) materials. Thus, the probability of fire spreading through a window can be at maximum $1 \cdot 10^{-5}$ per year for fires spreading though one window. If it is assumed that the initial fire is in a room or spreads to an apartment with 4 sufficiently large windows which break, then the probability of fire spread to apartments above will be (the worst case upper limit) $4 \cdot 10^{-5}$ per year. For the rendering protected EPS ETICS facade this worst case upper limit of fire spread probability would be $4.8 \cdot 10^{-5}$ per year.

A common way of expressing risk is an F-N curve, where the frequency (F) of an incident is plotted as function of the number of fatalities $(\mathrm{N})$ for that incident. An example of F-N curve of fire fatalities illustrating the significant differences in acceptance levels between single and multiple casualties is shown in Figure 5 [23].

The number of fire deaths per apartment building fire according to Finnish [24] and Swedish [25] statistics is $1-2 \cdot 10^{-2}$. Combining this with the estimated fire spread probabilities through windows leads to fire death probability upper limit of no more than $10^{-6}$ per building fire per year $\left(0.8 \cdot 10^{-6}\right.$ for at least A2-s1, d0 facade and $1.0 \cdot 10^{-6}$ for EPS/rendering systems). According to the F-N curves of Figure 5 [23] this frequency is tolerable to accidents of about 6 or less fatalities. Since the average number of persons per apartment e.g. in Finland is two, the number of deaths foreseen in three apartments (as a consequence of fire spreading through windows to upper floors) remains below 6 because apartments are not occupied all the time. Therefore, it can be concluded that life safety objectives are reached.

\section{FIRE SAFETY DURING CONSTRUCTION AND RENOVATION}

Uncovered EPS with flame retardant can resist small ignition sources such as cigarettes or small flames and is classified to reaction to fire class E. Also under radiant exposure at low heat flux levels EPS with 


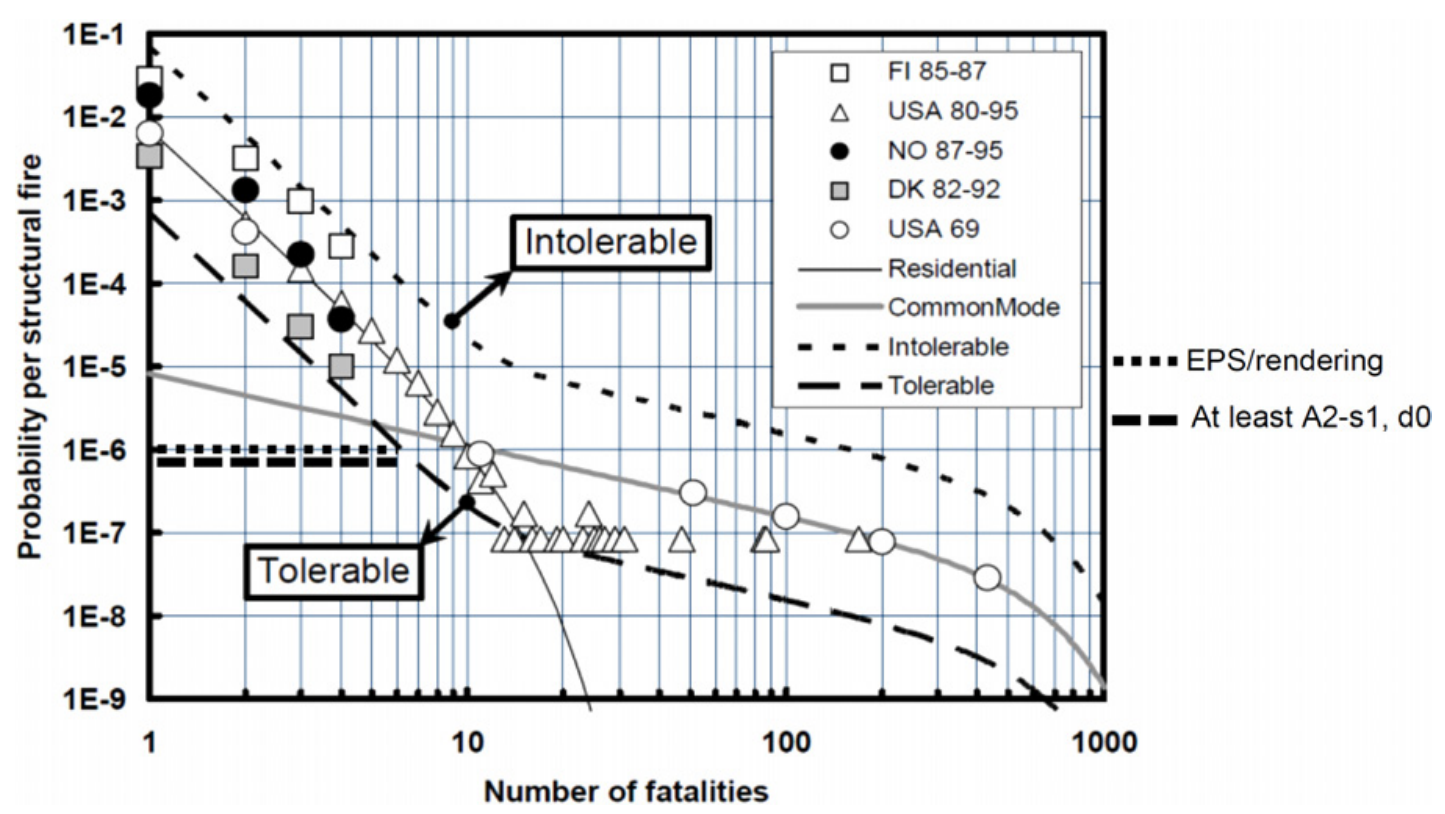

Figure 5. F-N curves based on statistical data, tolerable/intolerable limits [23] and present upper limit values for at least/nearly A2-s1, d0 facades and for EPS ETICS.

flame retardant is superior to EPS without flame retardant in terms of fire behaviour. At higher heat fluxes these differences are reduced and at $50 \mathrm{~kW} / \mathrm{m}^{2}$ the differences are not significant.

The main principles and actions concerning construction site fire safety for the time when EPS is uncovered during installation phase can be summarised as follows (see also European and national guidance documents [26-31]): a) Reduce the risks of ignition by minimizing the use of flammable liquids and gases and the amount of fire load, b) follow the hot work instructions, c) make sure that everybody involved understands all fire safety instructions, and d) if the apartments are occupied during the installation process, limit the time EPS insulation is uncovered and provide proper safety instructions and means for escape.

\section{CONCLUSIONS}

Effect of EPS insulation to the fire safety of the building has been studied by using fire safety engineering methods. Taking into account uncertainties and sensitivity analysis it was estimated that there is a small difference between the two studied facade types: The overall window break probability in the floors above for EPS ETICS facade is $2.3 \%$ and for at least A2-s1, d0 facade $1.9 \%$ per ignited fire. The estimated overall probability values for the window breaking in the floors above are on the upper limit compared to statistical data for which conservative values were used. Thus a safety factor is included in the results.

Concerning consequences for life safety the fire death probability was found to be not more than $10^{-6}$ per building fire $\left(0.8 \cdot 10^{-6}\right.$ for at least A2-s1, d0 facade and $1.0 \cdot 10^{-6}$ for EPS ETICS systems). When this value is compared with tolerable limit of F-N-curves (probability of an event and consequences in terms of number of deaths), it can be concluded that life safety objectives are reached.

Concerning construction site fire safety the following applies: Reduce the risks of ignition, follow the hot work instructions, ensure that everybody on the site knows and understands the fire safety 
$1^{\text {st }}$ International Seminar for Fire Safety of Facades, Paris (France), 2013

instructions, and if the apartments are occupied during the installation process, limit the time EPS insulation is uncovered and provide proper safety instructions and means for escape.

The financial support of EPS-rakennuseristeteollisuus, EPS-Bygg Plast och Kemiföretagen and EUMEPS is gratefully acknowledged.

\section{References}

[1] Hostikka, S., Keski-Rahkonen, O. \& Korhonen, T. 2003. Probabilistic Fire Simulator. Theory and User's Manual for Version 1.2. Espoo: VTT Publications 503. 72 p. + app. 1 p. ISBN 951-386235-6; 951-38-6236-4. http://www.vtt.fi/inf/pdf/publications/2003/P503.pdf

[2] Mikkola, E., Hakkarainen, T. \& Matala, A. Fire safety of EPS ETICS in residential multi-storey buildings. Espoo: VTT Technical Research Centre of Finland, 2013. 37 p. + app. 4 p. (Research Report VTT-R-04632-13)

[3] ETAG 004. Guideline for European Technical Approval of External thermal insulation composite systems with rendering. Brussels 2008. 143 p.

[4] EPS-eristeen käyttö ohutrapatussa julkisivussa. EPS-rakennuseristeteollisuus, syyskuu 2010. 6 p. + app. 6 p. (In Finnish)

[5] ISO 5660-1:2002. Reaction-to-fire tests - Heat release, smoke production and mass loss rate - Part 1: Heat release rate (cone calorimeter method). Geneva: International Organization for Standardization, 2002. 39 p.

[6] Mikkola, E. \& Kallonen, R. Combustion of chemical substances and the impact on the environment of the fire products. Cone calorimeter experiments. VTT Building Technology, Fire Technology. Espoo, 1994.

[7] Scudamore, M. J., Briggs, P. Prager, F. H. Cone calorimetry - A review of tests carried out on plastics for the association of plastic manufacturers in Europe. Fire and Materials. Vol. 15, pp. 65-84, 1991.

[8] Collier, P.C.R. and Baker, G.B. (2004). Improving the Fire Performance of Polystyrene Insulated Panel in New Zealand. BRANZ Report No. FCR 9. ISSN: 0113-3675.

[9] Collier, P.C.R. (2005). Flame Barriers for Foamed Plastics. BRANZ Study Report SR 144, BRANZ Ltd.

[10] Aho, H., Inha, T. \& Pentti, M. Fire safety of EPS-insulated structures. Tampere: Tampere University of Technology, Structural engineering, Fire laboratory, 2006. 106 p. + app. 38 p. (Research Report 134.) (In Finnish.)

[11] McGrattan, K., McDermott, R, Hostikka, S. and Floyd, J. Fire Dynamics Simulator (Version 5) User's Guide. National Institute of Standards and Technology, Gaithersburg, MD (2010) NIST Special Publication 1019-5.

[12] Korhonen, Timo \& Hietaniemi, Jukka. Fire Safety of Wooden Facades in Residential Suburb Multi-Storey Buildings. VTT Working Papers 32. Espoo 2005. 66 p. + app. 40 p.

[13] Keski-Rahkonen, O., Karhula, T. \& Hostikka S. 2009. Palokuormien jakaumat palokuolemien ehkäisykeinojen arviointiohjelmassa (Fire load distributions analyzed for the fire death prevention research program). Pelastustieto, Palontorjuntatekniikka-erikoisnumero, pp. 108-114. Palotutkimuksen päivät, 25.-26.8.2009. Palo- ja pelastustieto Ry. (In Finnish)

[14] Holm, C. \& Oksanen, P. 1970. Palokuorman määrä kerrostalojen asuinhuoneistossa. Palontorjuntatekniikka, No. 2, pp 1-4. 1970. (In Finnish)

[15] Campbell, J. A. 1981. Confinement of Fire in Buildings. Fire Protection Handbook. NFPA Handbook. USA 1981.

[16] Bwalya, A., Sultan, M. \& Bénichou, N. 2004. A Pilot Survey of Fire Loads in Canadian Homes. Research Report No. 159. Ottawa, Canada 2004. 


\section{MATEC Web of Conferences}

[17] Carlsson, J. and Karlsson, B. Numerical Simulation of Fire Exposed Facades - An initial investigation. Lund University. Report 3123, Lund 2001.

[18] Hermodsson, T., Månsson, L. Facades: Fire testing of materials and constructions, a first proposal for a test method. Nordtest project 969-91. SP Technical Notes.

[19] MASSIVTRÄ project. Research report 27.2.2001. VTT.

[20] Hakkarainen, T. and Oksanen, T. Fire Safety Assessment of Wooden Facades. Fire and Materials. Vol. 26, pp. 7-27, 2002.

[21] Tillander, K., Oksanen, T. \& Kokki, E., 2009. Paloriskin arvioinnin tilastopohjaiset tiedot [Statistical data for fire risk assessment], VTT Tiedotteita - Research Notes 2479, VTT, Espoo, 106 p. + app. 5 p. (In Finnish).

[22] Tillander, K. 2004. Utilisation of statistics to assess fire risks in buildings. Espoo, VTT Building and Transport. 224 p. + app. 37 p. VTT Publications 537.

[23] Korhonen, Timo; Hostikka, Simo; Keski-Rahkonen, Olavi. A proposal for the goals and new techniques of modeling pedestrian evacuation in fires. Proceedings of the $8^{\text {th }}$ International Symposium on Fire Safety Science. Beijing, China, 18-23 Sept. 2005. Gottuk, D. \& Lattimer, B. (eds.). International Association of Fire Safety Science (2005), 557-569.

[24] Finnish Rescue Services Pocket Statistics 2007-2011. Emergency Services College, 2012. 32 p.

[25] Fire and fire protection in homes and public buildings. An analysis of Swedish fire statistics and fire protection strategies. Kemi Report Nr 1/06. Stockholm 2006. 69 p.

[26] Fire prevention on construction sites. European Guideline. CFPA-E No 21:2012 F. Copenhagen and Stockholm 2012. 22 p.

[27] Fire safety basics for hot work operatives. European Guideline. CFPA Guideline No12: 2012F. Copenhagen and Stockholm 2012. 22 p.

[28] Fire safety during renovation of a building (Paloturvallisuus rakennuksen korjaustyön aikana), SPEK opastaa 25: 2011 (In Finnish)

[29] Unverbindlicher Leitfaden für ein umfassendes Schutzkonzept. Baustellen. (Non-binding guide for a comprehensive safety concept. Construction sites). VdS 2021:2010-01 (01). 39 p. (In German)

[30] Brandskydd på byggarbetsplatser. Brandskyddsföreningen 2011. ISBN 978-91-7144-405-9. 56 p. (In Swedish)

[31] Bygg säkert med cellplast. EPS-bygg. 24 p. (In Swedish) 